Volume 6, Issue 3, May- June 2019, pp. 96-105, Article ID: JOM_06_03_011

Available online at

http://www.iaeme.com/JOM/issues.asp?JType=JOM\&VType=6\&IType=3

Journal Impact Factor (2019): 5.3165 (Calculated by GISI) www.jifactor.com

ISSN Print: 2347-3940 and ISSN Online: 2347-3959

DOI: 10.34218/JOM.6.3.2019.011

(C) IAEME Publication

\title{
"AN ANALYSIS ON THE ROLE OF SMARTPHONES IN ONLINE BUYING BEHAVIOUR OF CUSTOMERS IN KERALA"
}

\author{
Binil V. Rajan \\ Assistant Professor, Department of Commerce, \\ Naipunnya School of Management, Cherthala, Kerala, India
}

\begin{abstract}
The purpose of this paper is to analyse the role of smartphones in online buying behaviour of employed youth in Alappuzha District of Kerala. The paper analysis the factors that influence the buying behaviour of employed youth and also analyse the level of smartphone usage among the employed youth of Alappuzha District. The paper thus analyse various factors like purpose for which smartphones are used frequently, the payment method usually preferred by the customers in online purchases, the level of trust in banking transactions through online mode, the level of satisfaction about the data plans provided by the network providers, the most preferred online shopping sites, type of products usually purchased online, factors mostly considered while selecting a product online, the factors which restricts the customers from carrying out online shopping etc. The study is conducted with the help of a structured questionnaire and 143 samples were used for the analysis.
\end{abstract}

KEYWORDS: Purchasing Behaviour, Online purchasing Behaviour, Influence of smartphone.

Cite this Article: Binil V. Rajan, an Analysis on the Role of Smartphones in Online Buying Behaviour of Customers in Kerala. Journal of Management, 6(3), 2019, pp. 96105.

http://www.iaeme.com/jom/issues.asp?JType=JOM\&VType=6\&IType=3

\section{INTRODUCTION}

Internet has evolved a global phenomenon of shopping and buying goods and services by the customer. In order to compete in the market many leading companies have started using the internet to cut market cost and reduce the price of their product and service. By using the Internet facility, companies are able to convey, communicate and scatter information, to sell the product, to get the feedback and also to do satisfaction surveys with customers. Customers use the Internet for many purposes like to purchase online, price comparisons, analyse product features and post-sale service facilities they will get if they purchase the product from a particular shop. With the tremendous potential of the E-commerce market, the Internet also 
provides a unique chance for companies to more efficiently reach existing and potential consumers. Michael Aldrich, in 1979 invented online shopping in United Kingdom. The first online shopping system is introduced by a German company Intershop in 1994, Amazon launched its online shopping site in 1995 and in 1996 eBay appeared.

In the present 'e-era', Internet has become an integral part in our lives and has changed everything .Internet is becoming an important new channel of commerce in the range of business with a rapid development of new information technologies and increasing adoption and usage of internet by customers which will disrupt the existing retail formats. One of the business applications which conquered the new world is online shopping. New generation are adopting online purchase through virtual stores that exist in cyber space by using computer, mobile, television, tablets and other electronic devices within in a fraction of minute without an intermediary service. Thus, shopping in a traditional brick and mortar retail format like mom and pop stores and malls are becoming less popular.

Online shopping is the process where by consumers directly buy products or services from a seller in real time, without an intermediary service, over the internet. The sale or purchase transaction is done electronically in real time. Mobile commerce involves purchasing from an online retailer's mobile based online site or app. Now a days the traditional buying is challenged by the online marketers with the development of IT and its application in world of business. The internet totally changes our life style and style of shopping and online shopping becomes an integral part of our life. Online shopping developed with Business to Business as well as with Business to Consumers since everybody is on internet and development is going on each and every second for grabbing a better share of the market. Electronic Data Interchange allows companies to handle electronic transactions. Some big players had started to use Electronic Data Interchange as early as 1960 . The rail road industry was among the first to understand the importance of Electronic Data Interchange and start using the same. But in 1979 there was a hero of E-commerce, Michael Aldrich who was on a stroll in a supermarket with his wife, got an idea which changed it all for e-Commerce. Aldrich integrated a TV and a computer with telephone lines so as to start selling groceries online through this model. How they were able to tackle various situations is a different story altogether, but at the end of the day they came with a model that helped them launch the business of online shopping.

The modern culture is penetrating into our culture slowly. The lifestyles in metro cities are very fast moving and the number of nuclear families are increasing day by day. The working people has very less free time available to reach the market place to purchase products. In order to visit a conventional retail store, it requires travel and will take place during the hours of business. Online stores are available 24 x 7 and many customers have internet access both at work and home. Online shopping in India is in its nascent stage and is truly caching on. The trend pattern clearly states that the traditional stores will have enough business while the online shops increase their business through internet. So, more and more people are gaining confidence about purchasing products online. Meantime, online shopping trends are improving and posess a bright future. The internet is helping many business enterprises whether small scale or medium scale, which are joining hands with major Indian online sites to display their products and advertise their services. Competition is intensified with an expansion of products available in online market and it shows the increase of online purchasing behaviour. As a result of increased usage of Internet, dynamism in market and consumers attraction towards online buying, researchers are keen to uncover the currents driving and identify leading indicators of future success of online buying.

About $40 \%$ of the population in India are internet users. Despite being the second-largest users of internet in world, the penetration of electronic-commerce is much low compared to markets like the United States or France but is growing at an extraordinary rate, adding around 
6 million new users every month. The largest electronic-commerce companies in India were Amazon, Flipkart, Shop Clues, Paytm, Snapdeal and e-bay in 2017. Electronics and Apparel contributes to the biggest portion in terms of sales. According to Google India Research, by 2021 India is expected to generate hundred-billion-dollar online retail revenue out of which 35 billion dollars will be through fashion e-commerce. Online apparel sales are expected to grow at least four times in years to come. Another important and big segment in e-commerce is mobile/DTH recharge with nearly 1 million transactions daily by operator websites. Another new sector in e-commerce is online medicine, which sell complementary and alternative medicine or prescription medicine online. As there are no dedicated online pharmacy laws in India and it is permissible to sell prescription medicine online legally. Online sales of luxury products like jewellery also seems to be increased over the years. Almost all the retail brands have started entering into the market and they expect at least twenty percent sales through online in next $2-3$ years.

The need was felt to find out the role of smart phones in online buying behaviour of employed youth in Kerala. The objective of the paper is to evaluate the various factors which influence the online buying behaviour and to find how smart phones influences the buying behaviour of employed youth in Kerala. This paper uses a Questionnaire for assessing the role of smartphones in buying behaviour of employed youth in Alleppey District of Kerala State, India.

\section{REVIEW OF LITERATURE}

Mayer, Davis \& Schoorman, (1995) developed a new model by combining traditional marketing philosophy on customer motivation to buy and the trust model, where propensity for trust, a personality trait possessed by buyers is an important antecedent. Buyer with a high propensity for trust is likely to be a potential customer than a buyer with a lower propensity. Ability, benevolence and integrity are the main elements of trustworthiness.

Jarvenpaa, Todd, Jarvenpaa, and Todd (1997) proposed a new model of attitude, behavior, and shopping intention towards Internet shopping. It includes several indicators classified into four different categories like product value, quality services offered through the website, the shopping experience, and the risk perception of the online shopping.

Kunz (1997)in his study on Internet shopping found that online shoppers are opinion leaders, innovators, and domain specific to the Internet. The study also found that men are more likely to purchase via the Internet, and those who intend to shop online are likely to be young. People living in large metropolitan areas are less likely to shop online as compared to those living in suburban areas of small metropolitan populations.

Solomon (1998) in his study analysed the Consumer behaviour and found that it is the study of the processes involved with the selection, purchases, uses or disposes of products, services, ideas, or experiences to satisfy needs and desires.

Donthu \& Garcia (1999) studied about the consumer characteristics related to online shopping and it was found that consumers who seek convenience $\&$ variety do more shopping online. The study also found that such people are also more innovative and spontaneous than others.

Wolfinbarger \& Gilly, (2001) in the study suggested that Consumer's attitude and shopping intentions on the Internet are guided by a wide variety of situational factors, like geographical distance, lack of mobility, time pressure, attractiveness of alternatives and need for special items. Important attributes of online shopping are convenience and accessibility to most consumers. 
Forsythe \& Shi (2003) mentioned Internet users can be categorized in to two viz., Internet shoppers and Internet browsers. Internet shoppers are the people who shop online, whereas Internet browsers are the people who just browse the Internet for other than shopping purposes.

Hansen (2005) in a study analysed that consumers are much concerned with the missing social interaction when shopping online. Self-transcendence emphasizes equality and maintaining good social relations, whereas self-enhancement focuses on wealth and power and getting things done effectively.

Chang, Cheung, and Lai (2005) studied the categories of variables, which influence online shopping activity. Perceived features of the web sale channel are the first one which includes risk, online shopping experiences, advantage, service quality, trust. The second category is a website and product characteristics which are risk reduction measures, site features, and product characteristics; and the last group is consumer features. Various types of features, demographic variables, consumer shopping orientations, consumer innovativeness and psychological variables, computer, Internet knowledge, and usages influences consumer characteristics.

Sheth \&Vittal, (2007) studied that the buying behaviour of Indian consumers are scarce, dynamics in India are different from that of the European countries, where shopping is a family activity with nearly 70 percent of shoppers going to stores always with the family, with 74 percent of them feels shopping as the best way to spend time with the family. The familyoriented shopping as a preference was found to be very important across regions and cities, income segments and age groups in India.

Vijay and Balaji (2009), revealed that most of the consumers all over the world, are increasingly changing from the crowded stores to the easy online shopping format. A survey among 150 internet users was carried out to study why some chooses online purchase while others do not. The results say that convenience and saving of time motivates the Indian consumers to shop online; while security and privacy concerns dissuade them from doing so.

C. Liao, Palvia, \& Lin, (2010) studies that the entire online purchase has even been divided into two stages: first consisting of searching, comparing and selecting, placing an order termed as ordering stage and second stage is order tracking and keeping or returning termed as order fulfilment stage.

Adrita Goswami et.al (2013). Studied about the Customer Satisfaction towards Online Shopping with Special Reference to Teenage Group of Jorhat Town concludes that online consumers are satisfied. This research clearly indicates that online marketer should give more importance on price factor and after sale service factor the most. In this era of competitions, all the online marketers should have to stress more on the customer's satisfaction to retain the existing customers and have to offer new scheme day by day to attract the new customers.

Huseynov and Y1ldirım (2014) in the study states that the lack of physical interaction tends to be the critical issuesmakers in online retail sales followed by the privacy of individual information and security of financial transactions over the Internet.

Singh, (2014) described that the online shopping is becoming a trend among Indians as they find it is more comfortable, time saving and convenient. When consumers purchase goods and services online, they are influenced by various determinants, including price, trust, and convenience. Intermediaries, physical storage, etc. are not present in online stores thus it can assist its clients with reasonably priced products. The ease and comfort provided by these stores for $24 \times 7$ have made very easy shopping for consumers worldwide.

\subsection{OBJECTIVES OF THE STUDY}

1. To analyse the factors affecting the online buying behaviour.

2. Analysing the influence of smartphones in online buying behaviour. 
An Analysis on the Role of Smartphones in Online Buying Behaviour of Customers in Kerala

3. To analyse the probable problems faced by customers in Online Buying.

4. To analyse the level of smartphone usage among the employed youths in Alappuzha District of Kerala.

\subsection{LIMITATIONS OF THE STUDY}

1. The study is limited to employed youth of Alappuzha District.

2. All the limitations of Questionnaire data collection methods will be there.

\section{RESEARCH METHODOLOGY}

The study is based on primary as well as the secondary data. An attempt has been made to know the role of smartphones in the online buying behaviour and the factors influencing it by selecting 150 employed youth, in Alappuzha district. Out of the 150 samples selected, 7 were rejected due to incomplete responses. Convenience sampling method is used to select these respondents. A structured questionnaire is used to collect the information from the respondents. Various journals, books and websites form the secondary sources of information.

\subsection{DATA ANALYSIS AND INTERPRETATION}

Table 1: showing the usage of Mobile phones per day.

\begin{tabular}{|c|c|c|}
\hline Responses & No. of Respondents & Percentage \\
\hline Less than 2 hour & 3 & 2 \\
\hline 2 hour -4 hour & 14 & 10 \\
\hline 4 hour -6 hour & 54 & 38 \\
\hline 6 hour- 8 hour & 65 & 45 \\
\hline Above 8 hour & 7 & 5 \\
\hline TOTAL & 143 & 100 \\
\hline
\end{tabular}

Inference: Table 1 reveals that about half of the (45\%) of the respondents uses mobile for 6 hours to 8 hours daily.

Table 2: showing the frequency of using mobile phones.

\begin{tabular}{|c|c|c|c|c|c|c|c|c|c|c|c|c|}
\hline \multirow{2}{*}{ Responses } & \multicolumn{2}{|c|}{ Never } & \multicolumn{2}{c|}{ Rarely } & \multicolumn{2}{c|}{ Sometimes } & \multicolumn{2}{c|}{ Often } & \multicolumn{2}{c|}{ Always } & \multicolumn{2}{c|}{ TOTAL } \\
\cline { 2 - 15 } & $\mathrm{F}$ & $\%$ & $\mathrm{~F}$ & $\%$ & $\mathrm{~F}$ & $\%$ & $\mathrm{~F}$ & $\%$ & $\mathrm{~F}$ & $\%$ & $\mathrm{~F}$ & $\%$ \\
\hline Internet & 0 & 0 & 3 & 2 & 8 & 6 & 60 & 42 & 72 & 50 & 143 & 100 \\
\hline Gaming & 57 & 40 & 74 & 52 & 8 & 5 & 4 & 3 & 0 & 0 & 143 & 100 \\
\hline Phone call & 0 & 0 & 2 & 1 & 3 & 2 & 85 & 60 & 53 & 37 & 143 & 100 \\
\hline WhatsApp & 0 & 0 & 0 & 0 & 18 & 13 & 60 & 42 & 65 & 45 & 143 & 100 \\
\hline
\end{tabular}

Inference: Table 2 reveals that about half of the respondents (50\%) always use mobile phone for Internet access, which is followed by WhatsApp usage (45\%).

Table 3: showing the payment method usually preferred in online shopping.

\begin{tabular}{|c|c|c|}
\hline Responses & No. of Respondents & Percentage \\
\hline Cash on Delivery & 102 & 71 \\
\hline Credit Cards & 6 & 4 \\
\hline Debit /ATM Cards & 35 & 25 \\
\hline Net Banking & 0 & 0 \\
\hline BHIM UPI & 0 & 0 \\
\hline PayPal & 0 & 0 \\
\hline TOTAL & 143 & 100 \\
\hline
\end{tabular}


Inference: Table 3 reveals that Majority (71\%) of the respondents use Cash on Delivery for payments in Online shopping.

Table 4: showing the level of trust in bank transactions through mobile.

\begin{tabular}{|c|c|c|}
\hline Responses & No. of Respondents & Percentage \\
\hline Extremely High & 20 & 14 \\
\hline High & 97 & 68 \\
\hline Moderate & 23 & 16 \\
\hline Low & 3 & 2 \\
\hline Extremely Low & 0 & 0 \\
\hline TOTAL & 143 & 100 \\
\hline
\end{tabular}

Inference: Table 4 reveals that Majority of the respondents (68\%) are having a high level of trust in bank transactions through mobile.

Table 5: showing the number of sim cards possessed.

\begin{tabular}{|c|c|c|}
\hline Responses & No. of Respondents & Percentage \\
\hline 1 & 3 & 2 \\
\hline 2 & 112 & 78 \\
\hline More than 2 & 28 & 20 \\
\hline TOTAL & 143 & 100 \\
\hline
\end{tabular}

Inference: Table 5 reveals that Majority (78\%) of the respondents possess 2 sim cards. $20 \%$ of the respondents have more than 2 sim cards with them.

Table 6: showing the network provider for data usage preferred.

\begin{tabular}{|c|c|c|}
\hline Responses & No. of Respondents & Percentage \\
\hline Airtel & 6 & 4 \\
\hline Jio & 58 & 41 \\
\hline Idea & 55 & 38 \\
\hline BSNL & 7 & 5 \\
\hline Vodafone & 17 & 12 \\
\hline TOTAL & 143 & 100 \\
\hline
\end{tabular}

Inference: Table 6 reveals that Most of the respondents (41\%) preferred Jio as network provider for data which is followed by Idea (38\%). Only $4 \%$ of the respondents preferred Airtel as their network provider for data.

Table 7: showing the level of satisfaction of data plans provided by network provider.

\begin{tabular}{|c|c|c|}
\hline Responses & No. of Respondents & Percentage \\
\hline Highly Satisfied & 9 & 6 \\
\hline Satisfied & 75 & 53 \\
\hline Neutral & 53 & 37 \\
\hline Dissatisfied & 6 & 4 \\
\hline Highly Dissatisfied & 0 & 0 \\
\hline TOTAL & 143 & 100 \\
\hline
\end{tabular}

Inference: Table 7 reveals that Majority of the respondents (53\%) was satisfied with the data plans provided by the network provider. 
An Analysis on the Role of Smartphones in Online Buying Behaviour of Customers in Kerala

Table 8: showing the make of mobile.

\begin{tabular}{|l|l|l|}
\hline Responses & No. of Respondents & Percentage \\
\hline Samsung & 38 & 27 \\
\hline Xiaomi & 53 & 37 \\
\hline Realme & 11 & 8 \\
\hline Vivo & 12 & 8 \\
\hline Oppo & 8 & 6 \\
\hline Oneplus & 6 & 4 \\
\hline Apple & 3 & 2 \\
\hline Others & 12 & 8 \\
\hline TOTAL & 143 & 100 \\
\hline
\end{tabular}

Inference: Table 8 reveals that Most of the respondents uses Xiaomi (37\%) mobiles which is followed by Samsung (27\%).Only 3\% of the respondents under study possessed Apple mobiles.

Table 9: showing the most preferred Online shopping site.

\begin{tabular}{|c|c|c|}
\hline Responses & No. of Respondents & Percentage \\
\hline Flipkart & 79 & 55 \\
\hline Snapdeal & 14 & 10 \\
\hline Jabong & 12 & 8 \\
\hline Amazon & 38 & 27 \\
\hline Myntra & 0 & 0 \\
\hline Others & 0 & 100 \\
\hline TOTAL & 143 & 0 \\
\hline
\end{tabular}

Inference: Table 9 reveals that half of the respondents (50\%) preferred Flipkart which is followed by Amazon (27\%) as their shopping site.

Table 10: showing the type of products usually purchase online using Mobile.

\begin{tabular}{|l|l|l|}
\hline Responses & No. of Respondents & Percentage \\
\hline Movie Tickets & 23 & 16 \\
\hline Train/ Flight Tickets & 11 & 8 \\
\hline Food orders & 0 & 0 \\
\hline Computer Peripherals & 16 & 11 \\
\hline Electronics & 19 & 13 \\
\hline Gifts & 4 & 3 \\
\hline Dress \& Accessories & 33 & 23 \\
\hline Kids items & 14 & 10 \\
\hline Books & 19 & 13 \\
\hline Others & 4 & 3 \\
\hline TOTAL & 143 & 100 \\
\hline
\end{tabular}

Inference: Table 10 reveals that $23 \%$ of the respondents usually purchase dress and accessories which is followed by the purchase of movie tickets (16\%).No respondent under this study ordered food online. 
Table 11: showing the factors considering while selecting a product.

\begin{tabular}{|c|c|c|c|c|c|c|c|c|c|c|c|c|c|}
\hline \multirow{2}{*}{ Responses } & \multicolumn{2}{|c|}{ Never } & \multicolumn{2}{c|}{ Rarely } & \multicolumn{2}{c|}{ Sometimes } & \multicolumn{2}{c|}{ Often } & \multicolumn{2}{c|}{ Always } & \multicolumn{2}{c|}{ TOTAL } \\
\cline { 2 - 14 } & $\mathrm{F}$ & $\%$ & $\mathrm{~F}$ & $\%$ & $\mathrm{~F}$ & $\%$ & $\mathrm{~F}$ & $\%$ & $\mathrm{~F}$ & $\%$ & $\mathrm{~F}$ & $\%$ \\
\hline $\begin{array}{c}\text { Reviews \& } \\
\text { Rating }\end{array}$ & 0 & 0 & 4 & 3 & 18 & 13 & 36 & 25 & 85 & 59 & 143 & 100 \\
\hline $\begin{array}{c}\text { Price of the } \\
\text { product }\end{array}$ & 0 & 0 & 11 & 8 & 50 & 35 & 70 & 49 & 12 & 8 & 143 & 100 \\
\hline Discount & 0 & 0 & 14 & 10 & 48 & 33 & 50 & 35 & 31 & 22 & 143 & 100 \\
\hline $\begin{array}{c}\text { Price of } \\
\text { Substitute } \\
\text { products }\end{array}$ & 0 & 0 & 0 & 0 & 28 & 20 & 42 & 29 & 72 & 51 & 143 & 100 \\
\hline $\begin{array}{c}\text { Delivery time } \\
\text { Product }\end{array}$ & 0 & 0 & 95 & 66 & 48 & 34 & 0 & 0 & 0 & 0 & 143 & 100 \\
\hline Description & 0 & 0 & 50 & 35 & 65 & 45 & 28 & 20 & 0 & 0 & 143 & 100 \\
\hline
\end{tabular}

Inference: Table 11 reveals that the most important factor considered while selecting a product online are 'Reviews and Ratings' (59\%) which is followed by the 'price of the substitute products' (51\%).

Table 12: showing the factors which mostly attracted for online shopping.

\begin{tabular}{|c|c|c|}
\hline Responses & No. of Respondents & Percentage \\
\hline Home Delivery & 78 & 55 \\
\hline Varied Product Substitutes & 12 & 8 \\
\hline Shopping at any time & 35 & 24 \\
\hline Trust in reviews \& ratings & 18 & 13 \\
\hline TOTAL & 143 & 100 \\
\hline
\end{tabular}

Inference: Table 12 reveals that Majority of the respondents (55\%) are attracted towards 'Home Delivery' provided by online shopping sites the most which is followed by the 'Shopping at any time' feature (24\%). Only $13 \%$ of the respondents under study is attracted towards the trust in reviews and ratings.

Table 13: showing the factors that restricts you from online shopping.

\begin{tabular}{|c|c|c|c|c|c|c|c|c|c|c|c|c|}
\hline \multirow{2}{*}{ Responses } & \multicolumn{2}{|c|}{$\begin{array}{c}\text { Strongly } \\
\text { Disagree }\end{array}$} & \multicolumn{2}{c|}{ Disagree } & \multicolumn{2}{c|}{ Neutral } & \multicolumn{2}{c|}{ Agree } & \multicolumn{2}{c|}{$\begin{array}{c}\text { Strongly } \\
\text { Agree }\end{array}$} & \multicolumn{2}{|c|}{ TOTAL } \\
\cline { 2 - 14 } & $\mathrm{F}$ & $\%$ & $\mathrm{~F}$ & $\%$ & $\mathrm{~F}$ & $\%$ & $\mathrm{~F}$ & $\%$ & $\mathrm{~F}$ & $\%$ & $\mathrm{~F}$ & $\%$ \\
\hline $\begin{array}{c}\text { Low Quality } \\
\text { than expected }\end{array}$ & 2 & 1 & 21 & 15 & 81 & 57 & 20 & 14 & 19 & 13 & 143 & 100 \\
\hline $\begin{array}{c}\text { Problem in } \\
\text { Warranty } \\
\text { Claims }\end{array}$ & 0 & 0 & 6 & 4 & 34 & 24 & 65 & 45 & 38 & 27 & 143 & 100 \\
\hline $\begin{array}{c}\text { Fraud in Online } \\
\text { Banking }\end{array}$ & 0 & 0 & 21 & 15 & 99 & 69 & 23 & 16 & 0 & 0 & 143 & 100 \\
\hline $\begin{array}{c}\text { Long time } \\
\text { period for } \\
\text { delivery }\end{array}$ & 0 & 0 & 61 & 43 & 78 & 54 & 4 & 3 & 0 & 0 & 143 & 100 \\
\hline
\end{tabular}


An Analysis on the Role of Smartphones in Online Buying Behaviour of Customers in Kerala

\begin{tabular}{|c|c|c|c|c|c|c|c|c|c|c|c|c|}
\hline $\begin{array}{c}\text { Privacy of } \\
\text { Information }\end{array}$ & 8 & 6 & 22 & 15 & 97 & 68 & 16 & 11 & 0 & 0 & 143 & 100 \\
\hline $\begin{array}{c}\text { Difficulty in } \\
\text { Returning } \\
\text { Products }\end{array}$ & 0 & 0 & 0 & 0 & 6 & 4 & 126 & 88 & 11 & 8 & 143 & 100 \\
\hline $\begin{array}{c}\text { Previous Bad } \\
\text { Experiences }\end{array}$ & 0 & 0 & 4 & 3 & 10 & 7 & 96 & 67 & 33 & 23 & 143 & 100 \\
\hline
\end{tabular}

Inference: Table 13 reveals that $(88 \%)$ of the respondents agree that there is difficulty in returning products and $(65 \%)$ agree that there are problems with the warranty claims.

\section{FINDINGS}

1. About half of the ( $45 \%)$ of the respondents uses mobile for 6 hours to 8 hours daily.

2. Fifty percent of the respondents always use mobile phone for Internet access, which is followed by WhatsApp usage (45\%).

3. Majority $(71 \%)$ of the respondents use Cash on Delivery for payments in Online shopping.

4. Majority of the respondents $(68 \%)$ are having a high level of trust in bank transactions through mobile.

5. Almost all (78\%) of the respondents possess 2 sim cards.

6. Most of the respondents ( $41 \%)$ preferred Jio as network provider for data which is followed by Idea (38\%).

7. Majority of the respondents (53\%) was satisfied with the data plans provided by the network provider.

8. Most of the respondents uses Xiaomi (37\%) mobiles which is followed by Samsung $(27 \%)$.

9. Half of the respondents $(50 \%)$ preferred Flipkart which is followed by Amazon $(27 \%)$ as their shopping site.

10. $23 \%$ of the respondents usually purchase dress and accessories which is followed by the purchase of movie tickets $(16 \%)$. No respondent under this study ordered food online.

11. The most important factor considered while selecting a product online are 'Reviews and Ratings' (59\%) which is followed by the 'price of the substitute products' $(51 \%)$.

12. Majority of the respondents (55\%) are attracted towards 'Home Delivery' provided by online shopping sites the most which is followed by the 'Shopping at any time' feature $(24 \%)$.

13. Almost all $(88 \%)$ of the respondents agree that there is difficulty in returning products and $(65 \%)$ agree that there are problems with the warranty claims.

\section{CONCLUSION}

As we are going through an e-era, the technology is developing at a rapid speed and of course the development in smartphone technologies are immense. Now, the purview of smartphones has changed a lot from mere purpose of phone calls to a mini-personal computer. The change in technology has influenced consumers buying habit also to a large extent. The statistics from secondary data and the results of this research clearly explains the increasing tendency to buy 
goods online by the customers. As we continue the technological innovations, the scope of online shopping also have a greater future which of course is related to technological devices like smartphones.

\section{REFERENCES}

[1] Adrita Goswami et.al, (2013). Customer Satisfaction towards Online Shopping with Special Reference to Teenage Group of Jorhat Town Paripex - Indian Journal of Research, Vol: 3, Issue: 4, May 2013,239-241.

[2] Chang, M. K., Cheung, W., \& Lai, V. S. (2005). Literature derived reference models for the adoption of online shopping. Information and Management.

[3] Donthu, N. and Garcia, A. (1999), 'The Internet Shopper', Journal of Advertising Research, 52-58.

[4] Forsythe, S.M. \& Shi, B. (2003). Consumer patronage and risk perceptions in internet shopping. Journal of Business Research, 56(11), 867-875.

[5] Hansen, T. (2005). The online grocery consumer. Working Paper No. 1, Department of Marketing, Copenhagen Business School, Frederiksberg.

[6] Huseynov, F., \& Yıldırım, S. Ö. (2014). Internet users' attitudes toward business-toconsumer online shopping: A survey. Information Development, 32(3), 452-465.

[7] Jarvenpaa, S. L., \& Todd, P. A. (1997). Consumer reactions to electronic shopping on the world wide web.

[8] Kunz, M.B. (1997), "On-line customers: identifying store, product and consumer attributes which influences shopping on the Internet". Published doctoral dissertation. The University of Tennessee, Knoxville.

[9] Liao, C., Palvia, P., \& Lin, H. (2010). Stage antecedents of consumer online buying behavior. Electron Markets, 20, 53-65.

[10] Mayer, R.C., Davis, J.H. \& Schoorman, F.D. (1995). An integrative model of organizational trust. Academy of Management Review, 709-734.)

[11] Retrieved from https://chhattisgarhrojgar.com/article/Online-shopping-in-India-13788.

[12] Retrieved from https://en.wikipedia.org/wiki/E-commerce_in_India.

[13] Sheth, K.N. \& Vittal, I. (2007). India: Shopping with the family. The McKinsey Quarterly. Retrieved from http://ww.mckinseyquarterly.com.

[14] Singh, P. 2014. Consumer's Buying Behaviour towards Online Shopping. National Monthly Refereed Journal of Research in Commerce \& Management.

[15] Solomon, M. R., "Consumer behaviour”, New York, NY: Prentice Hall, 1998

[16] Vijay, S. T. and Balaji, M. S. 2009. Influencing the online consumer behavior: the web experience. Internet Research. 111-126.

[17] Wolfinbarger, M. \& Gilly, M. (2001). Shopping online for freedom, control and fun. California Management Review, 34-56. 